Research Article

\title{
Cytogenetics and DNA barcode reveal an undescribed Apareiodon species (Characiformes: Parodontidae)
}

Emanoel Oliveira dos Santos ${ }^{1}$, Geize Aparecida Deon ${ }^{2}$, Rafael Bonfim de Almeida ${ }^{1}$, Ezequiel Aguiar de Oliveira $^{3}$, Viviane Nogaroto ${ }^{2}$, Hugmar Pains da Silva ${ }^{4}$, Carla Simone Pavanelli ${ }^{5}$, Marta Margarete Cestari ${ }^{1}$, Luiz Antonio Carlos Bertollo ${ }^{3}$, Orlando Moreira-Filho ${ }^{3}$ and Marcelo Ricardo Vicari ${ }^{1,2}$ iD

${ }^{1}$ Departamento de Genética, Programa de Pós-Graduação em Genética, Universidade Federal do Paraná, Curitiba, PR, Brazil.

${ }^{2}$ Departamento de Biologia Estrutural, Molecular e Genética, Universidade Estadual de Ponta Grossa, Ponta Grossa, PR, Brazil.

${ }^{3}$ Departamento de Genética e Evolução, Universidade Federal de São Carlos, São Carlos, São Paulo, SP, Brazil.

${ }^{4}$ Laboratório de Citogenética e Genética Animal, Instituto de Biociências, Universidade Federal de Mato Grosso, Cuiabá, MT, Brazil.

${ }^{5}$ Núcleo de Pesquisas em Limnologia, Ictiologia e Aquicultura (Nupélia), Universidade Estadual de Maringá, Maringá, PR, Brazil.

\begin{abstract}
Parodontidae is a small group of fish and some species are particularly difficult to identify due to the lack of sufficiently consistent morphological traits. Cytogenetically, the species possess $2 n=54$ chromosomes and are either sex-homomorphic or sex-heteromorphic (regarding its chromosomes). We evaluated data on color, tooth morphology, cytogenetics, and mitochondrial markers (COI) in Apareiodon specimens from the Aripuanã River (Amazon ba$\mathrm{sin}$ ) and the results were compared to other congeneric taxa. Morphological results show an overlap of body color and tooth morphology to other known Apareiodon. The cytogenetics data showed that the $2 n=54$ chromosomes, 50 $\mathrm{m} / \mathrm{sm}+4 \mathrm{st}$ and, a ZZ/ZW sex chromosome system in Apareiodon sp. are common to other species of the genus. However, the number and chromosomal localization of the 45S ribosomal and pPh2004 satellite DNA sites, in addition to W chromosome localization of the pPh2004 appear to be exclusive cytogenetic features in Apareiodon sp. Our phylogenetic tree revealed well-supported clades and confirmed, by barcode species delimitation analysis, a new Molecular Operational Taxonomic Unit (MOTU) for Apareiodon sp. (Aripuanã River). As a whole, the above features support the occurrence of a new species of the Apareiodon, thus far unknown for the Parodontidae.
\end{abstract}

Keywords: Chromosomal differentiation, hidden diversity, repetitive DNA, sex chromosomes.

Received: March 03, 2018; Accepted: August 01, 2018.

\section{Introduction}

The family Parodontidae is currently composed of three genera: Apareiodon Eigenmann, 1916; Parodon Valenciennes, 1849 and Saccodon Kner, 1863 (Pavanelli, 2003), with 32 valid species (Eschmeyer and Fong, 2017). Its species can be differentiated from the other Characiformes by the following combined features: an edentulous lower jaw in the anterior region and spatulate mandible, pedunculated and multicuspided premaxillary teeth with wide distal border distributed in a single series,

Send correspondence to Marcelo Ricardo Vicari. Departamento de Biologia Estrutural, Molecular e Genética, Universidade Estadual de Ponta Grossa, Av. Carlos Cavalcanti, 4748, 84030-900, Ponta Grossa, PR, Brazil. E-mail: vicarimr@uepg.br and by the absence of upper lip and fontanelle (Pavanelli, 2003). The genera are mainly characterized by variation in the number of undivided rays in the pectoral fins. However, the color pattern with one regular black longitudinal stripe or several vertical bands, in addition to the shape and number of the tooth cusps adjacent to the premaxillary symphysial tooth, can also be used in the species identification (Pavanelli, 2003).

Cytogenetic analyzes in Parodontidae revealed a conserved diploid number of 54 chromosomes, most of them meta/submetacentric, with few or none subtelocentric chromosome (Moreira-Filho et al., 1980; Jesus and MoreiraFilho, 2000; Rosa et al., 2006; Vicari et al., 2006). Acrocentric chromosomes are an exception, only found in A. affinis of the lower Paraná River system (Jorge and 
Moreira-Filho, 2000, 2004; do Nascimento et al., 2018). Differences in karyotypes, such as distinct karyotypic formulas, number and localization of the satellite DNA pPh2004 and 18S and 5S rDNA sites, distribution of the heterochromatic bands and occurrence of sex chromosomes (Moreira-Filho et al., 1984, 1985; Bellafronte et al., 2011, 2012; Schemberger et al., 2011, 2014, 2016; Ziemniczak et al., 2014) appear as exclusive derived species features.

However, one of the most outstanding cytogenetic characteristics in the differentiation of Parodontidae species is the occurrence of sex chromosome systems. This way, besides species without heteromorphic sex chromosomes and with proto-sex ones, heteromorphic ZZ/ZW sex chromosomes and multiple sex systems of the $\mathrm{ZZ} / \mathrm{ZW}_{1} \mathrm{~W}_{2}$ type also occur (Schemberger et al., 2011). Heterocromatization is commonly associated to the morphological differentiation of the $\mathrm{W}$ chromosome (Centofante et al., 2002; Vicente et al., 2003; Vicari et al., 2006; Schemberger et al., 2011; Bellafronte et al., 2012). Accumulation of satellite sequences and transposable elements (TEs) were events responsible for molecular differentiation and erosion of the $\mathrm{W}$ chromosome gene activity, allowing the identification of pseudo-autosomal (PAR) and W specific (WSR) regions in Parodontidae (Schemberger et al., 2014; Ziemniczak et al., 2014). In addition, repetitive sequences also promoted the differentiation among autosomes, acting on the karyotypic diversification of this group (Bellafronte et al., 2011; Schemberger et al., 2011, 2014, 2016; Ziemniczak et al., 2014; Traldi et al., 2016; do Nascimento et al., 2018).

Integrative cytogenetic and DNA barcoding studies were effective in detecting chromosome evolution and species richness within supposedly homogeneous taxa of $A$. affinis (do Nascimento et al., 2018). Indeed, molecular analysis contributes to reveal a hidden biodiversity (Cunha et al., 2017; Ramirez et al., 2017; do Nascimento et al., 2018) and has been widely used for identification and delimitation of neotropical fish species (Carvalho et al., 2011; Pereira et al., 2011, 2013; Ramirez and Galetti Jr, 2015; Machado et al., 2016). In this sense, one of the most used genes for species identification is the mitochondrial cytochrome c oxidase subunit 1 (COI) gene, which was proposed by Hebert et al. (2003) as a DNA barcode methodology. Thus, DNA barcoding and population genetics can be used to define discrete genetic lineages, characterizing Molecular Operational Taxonomic Units (MOTUs) and/or revealing reciprocal monophyly (Floyd et al., 2002).

In this study, morphological patterns, chromosomal markers, and DNA barcode analysis were used with the objective of identifying a probable undescribed Apareiodon species from the Aripuanã River, Mato Grosso State, Brazil, here named as Apareiodon sp. In addition, we discuss the chromosomal evolution and species diversification within the Parodontidae.

\section{Material and Methods}

\section{Biological samples}

Chromosome studies were performed on 32 specimens (23 males and 9 females) of Apareiodon sp., collected in the Aripuanã River, Amazon basin (1009'57.8"S and $\left.59^{\circ} 26^{\prime} 54.9^{\prime \prime} \mathrm{W}\right)$. The chromosomal and DNA material was obtained from the Laboratory of Fish Cytogenetics of the Universidade Federal de São Carlos. The procedures were in agreement with the Ethics Committee for Animal Use of the Universidade Estadual de Ponta Grossa (Protocol: 29/2016). The fish were fixed in 10\% formalin and, after 48 hours, preserved in $70 \%$ ethanol. The specimens were identified based mainly on a black band on the third distal edge of the dorsal fin, but also on the combination of other morphological features, such as a black lateral band without up and downwards projections, two maxillary teeth, premaxillary teeth with a rounded cutting edge and 9 to 11 cusps, among others. Voucher specimens were deposited at the Coleção Ictiológica of Núcleo de Pesquisas em Limnologia, Ictiologia e Aquicultura (Nupélia) of Universidade Estadual de Maringá (NUP 19988).

\section{Analysis of body color, symphysial teeth, and tooth cusps}

Body color analysis was performed according to the method described by Pavanelli and Bristki (2003). Photos of unfixed and fixed specimens were used in order to ascertain the presence of the black dorsal-fin band and yellowish tone in Apareiodon sp. (Aripuanã River). Also, an extraction and analysis of the symphysial teeth was performed following do Nascimento et al. (2018). Teeth were photographed using a bright-field microscope (Olympus BX43) coupled to a DP72 CCD camera (Olympus) at 40x magnification for further counting of the cusps number.

\section{Chromosomal preparations}

Metaphase chromosomes were obtained from kidney cells, after in vivo treatment with colchicine and conventional air-drying preparation (Bertollo et al., 2015), and the chromosomal preparations in slides were submitted to conventional Giemsa staining $5 \%$ in phosphate buffer $(\mathrm{pH}=$ 6.8). Constitutive heterochromatin was detected by the Cbanding method (Sumner, 1972). The images were captured with a microscope (Olympus BX43) coupled to a DP72 CCD camera (Olympus), edited, and arranged into karyotypes using Adobe Photoshop software CC 2015. Homologous chromosomes were paired and arranged into metacentric-submetacentric $(\mathrm{m} / \mathrm{sm})$ and subtelocentric (st) groups, according to Levan et al. (1964). Two arms were considered for each one of such chromosome types to determine the fundamental number $(\mathrm{FN})$. 


\section{Fluorescence in situ hybridization (FISH)}

FISH was performed following Pinkel et al. (1986), and five types of probes were used to localize complementary sequences in the metaphase chromosomes of Apareiodon $\mathrm{sp}$. The following two sequences were isolated by PCR from the total genome of Apareiodon sp., according to the respective authors: 5S rDNA (Barros et al., 2017), 18S rDNA (Gross et al., 2010). In addition, the Parodon hilarii satellite DNA probe named $\mathrm{pPh} 2004$ (Vicente et al., 2003), the heterochromatic fraction of the $\mathrm{W}$ chromosome of Apareiodon sp., named WAp (Vicari et al., 2010), and a (GATA)n microsatellite probe (Traldi et al., 2013) were used.

The 18S rDNA and (GATA)n probes were labeled using digoxigenin-11-dUTP hapten (Jena Bioscience), while 5S rDNA, pPh 2004, and $\mathrm{W} A p$ were labeled using biotin-16 -dUTP hapten (Roche Applied Science). A general FISH protocol was followed under a stringency condition of $\sim 80 \%$ (2.5 ng/ $\mu \mathrm{L}$ probe, $50 \%$ formamide, $2 \mathrm{xSSC}, 10 \%$ dextran sulfate, $42^{\circ} \mathrm{C}$ for $16 \mathrm{~h}$ ). Post-hybridization washes were done at high stringency $\left(50 \%\right.$ formamide at $42{ }^{\circ} \mathrm{C}$ for $20 \mathrm{~min}, 0.1 \mathrm{xSSC}$ at $60{ }^{\circ} \mathrm{C}$ for $15 \mathrm{~min}$, and $4 \mathrm{xSSC} 0.05 \%$ Tween at room temperature for $10 \mathrm{~min}$ ). Streptavidin Alexa Fluor 488 (Molecular Probes) and an anti-digoxigenin rhodamine fab fragment (Roche Applied Science) were used for probe detection. The chromosomes were stained with DAPI $(0.2 \mu \mathrm{g} / \mathrm{mL})$ present in Vectashield mounting medium (Vector) and analyzed under epifluorescence microscopy.

\section{Molecular analysis}

For genomic DNA extraction, liver samples were used following the CTAB (cetyltrimethylammonium bromide) method of MURRAY AND Thompson (1980). DNA samples were used to amplify the barcode region of the mitochondrial gene cytochrome C oxidase subunit I (COI) by PCR. Amplification of the COI sequence was performed using the primers Fish Fl and Fish Rl (Ward et al., 2005). The reaction mix was composed by $1 \mathrm{x}$ Taq Reaction buffer (200 mM Tris pH 8.4, $500 \mathrm{mM} \mathrm{KCl),} 40 \mu \mathrm{M}$ dNTPs, $2 \mathrm{mM}$ $\mathrm{MgCl}_{2}, 2 \mathrm{U}$ of Taq DNA polymerase (Invitrogen, Carlsbad, USA), $0.2 \mu \mathrm{M}$ of each primer, and $100 \mathrm{ng}$ of DNA template. The following reaction program was used: initial denaturation for 2 min at $94^{\circ} \mathrm{C}, 35$ cycles of $94^{\circ} \mathrm{C}$ for $1 \mathrm{~min}$, $52{ }^{\circ} \mathrm{C}$ for $40 \mathrm{~s}, 72^{\circ} \mathrm{C}$ for $1 \mathrm{~min}$, and a final extension at 72 ${ }^{\circ} \mathrm{C}$ for $10 \mathrm{~min}$. After amplification, the samples were purified and submitted to nucleotide sequencing using an ABI-Prism 3500 Genetic Analyzer (Applied Biosystems).

COI sequences obtained for Apareiodon sp. from the Aripuanã River and for $A$. vittatus (Jangada River) were deposited in GeneBank (access numbers: MG827218 MG827229). Additionally, COI sequences of $A$. piracicabae (Passa Cinco River), A. affinis (Cuiabá River), and $A$. affinis (Passa Cinco River) described by Bellafronte et al. (2013) were used. All sequences were first analyzed with Geneious 8.1.9 software (Kearse et al., 2012) and aligned using ClustalW algorithm, where possible sequencing errors were checked using the BLAST tool against the data deposited in GenBank (NCBI).

Estimates of genetic distances were obtained using the MEGA software 7.0.14 (Kumar et al., 2016) under the Kimura-2-Parameters (K2P) evolution model (Kimura, $1980)$. Gene flow, haplotype (h), and nucleotide $(\pi)$ diversity analyses were performed by DnaSP software (Librado and Rozaz, 2009). Population structuring and analysis of molecular variance (AMOVA) (Excoffier et al., 1992), were performed by the Arlequin 3.5.2.2 software (Excoffier and Lischer, 2010). The PopArt 1.7 program was used to generate a haplotype network through the median joining criterion (Leigh and Bryant, 2015). Structural analysis was performed by assignments of each individual to the respective populations using Bayesian inference in Structure 2.3.4 software (Pritchard et al., 2000) and Bayesian Analysis of Population Structure - BAPS 6 (Corander et al., 2004; Corander and Marttinen, 2006). The Bayesian inference tree was generated with the MrBayes 3.2 program (Huelsenbeck and Ronquist, 2001; Ronquist and Huelsenbeck, 2003).

\section{Results}

\section{Color and teeth}

The Apareiodon sp. individuals showed a regular black longitudinal stripe extending from head to tail. The fin had a yellowish tone (pectoral, dorsal, caudal) and the end of the black stripe (Figure 1a). The symphysial teeth showed rounded edges, bearing 10 to 11 cusps (Figure 1b).

\section{Cytogenetics}

All specimens had $2 \mathrm{n}=54$ chromosomes, $\mathrm{FN}=108$, with $50 \mathrm{~m} / \mathrm{sm}+4 \mathrm{st}$ for both sexes. However, the $13^{\text {th }}$ pair appeared heteromorphic in females, revealing a ZZ/ZW sex chromosome system (Figure 2). Both $\mathrm{Z}$ and $\mathrm{W}$ chromosomes were metacentric in form, but the $\mathrm{W}$ one was much larger, corresponding to the second largest chromosome of the complement (Figure 2). The heterochromatin bands were mainly pericentromeric, in addition to some terminal bands (Figure $2 b, d$ ). While the $\mathrm{Z}$ chromosome presented only a small proximal heterochromatic band in the short arm, the $\mathrm{W}$ chromosome had most of its long arm heterochromatic (Figure 2b, d).

FISH analysis with the 5S rDNA probe showed that this multigene family is localized in the $p$ arm of pair 6 (Figure $3 \mathrm{a})$. The in situ localization of $18 \mathrm{~S}$ rDNA evidenced ten terminal clusters in pairs 2, 5, 9, 26 and 27, all in the long arms with exception of the pair 26 (Figure 3b). The DNA $\mathrm{p} P h 2004$ satellite was clustered in the terminal region of pairs 3, 5, 6 and, 11, in addition to ZW sex chromosomes, as well as the GATAn sequence although not in the same 


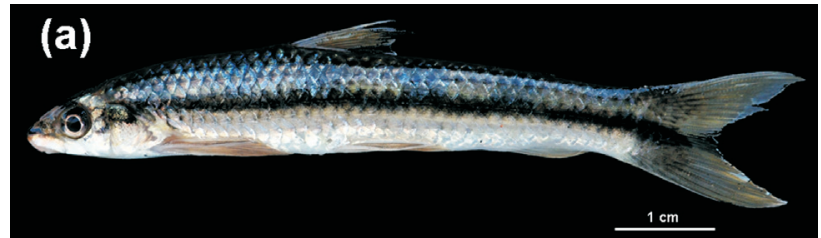

(b)

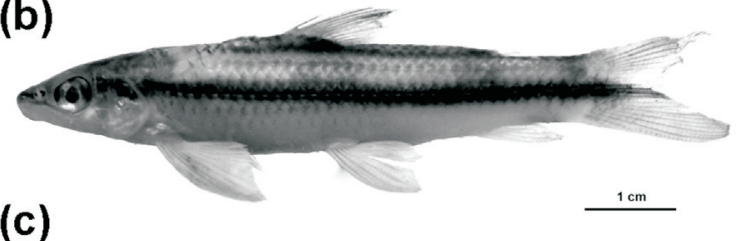

(c)

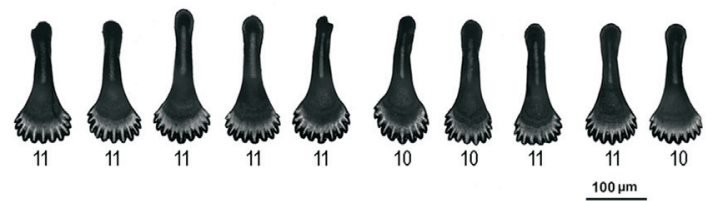

Figure 1 - Photograph of the Apareiodon sp. from the Aripuanã River: In (a) coloured image showing a regular black longitudinal stripe extending from head to tail; the fins have a yellowish tone (pectoral, dorsal, caudal) and the end of the black stripe; In (b) black and white image showing details of the fins. In (c) symphesial teeth images showing the tooth morphology and cusps number. The number in each tooth is the number of cusps.

chromosome pairs neither in the $\mathrm{Z}$ and $\mathrm{W}$ chromosomes (Figure $3 \mathrm{c}$ ). In addition, the heterochromatic $\mathrm{W} A p$ probe was also localized in the proximal region of the $q$ arm of the $\mathrm{Z}$ chromosome and in a great extent of the $\mathrm{q}$ arm of the $\mathrm{W}$ chromosome (Figure 3d).

\section{Molecular analysis}

Twenty-six fragments of the COI gene from different Apareiodon individuals were analyzed. The sequences did not show insertions, deletions, stop codons, or sequencing errors. The sequences contained 706 nucleotides, with 183
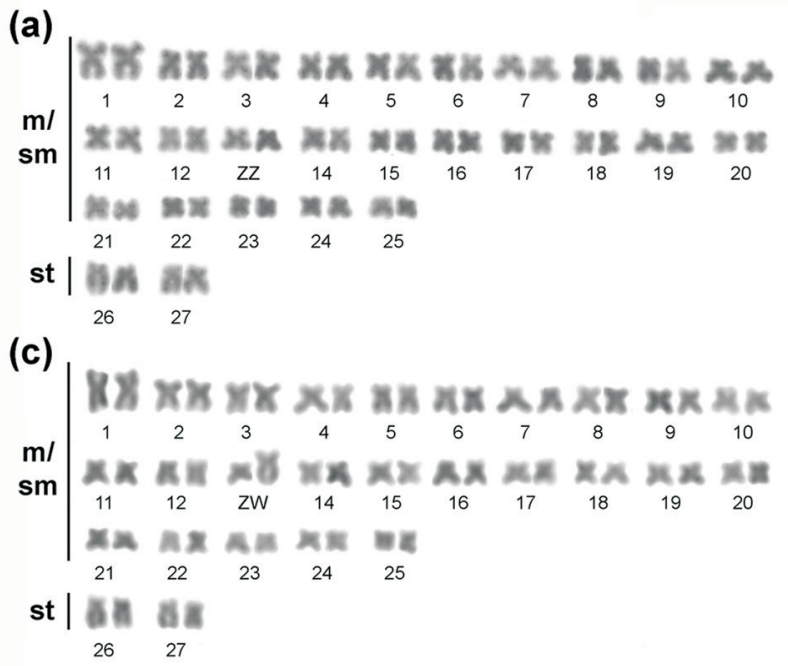

variable sites, and a nucleotide diversity of $\pi=0.13475$. The haplotype number considered was 16 , with a haplotype diversity of $\mathrm{h}=0.93231$.

Genetic K2P divergence among species ranged from 5.9 to $23.4 \%$ and, when considering only Apareiodon sp. (Aripuanã River) in comparison to the other Apareiodon species, the K2P genetic distance was 20.6 to $23.4 \%$ (Table 1). The maximum likelihood tree and Bayesian analysis considering the substitution TIM $2+\mathrm{G}$ model (Posada, 2003) given by Jmodeltest revealed five main consistent branches: Apareiodon sp. (Aripuanã River), A. vittatus, $A$. piracicabae, A. affinis (Cuiabá River), A. affinis (Passa Cinco River) (Figure 4). Leporinus piau was used as out-group in the tree and demonstrated the ancestral relationship with all species analyzed in-group.

The barcode sequences of the Apareiodon species analyzed were also used for the haplotype network construction. This network showed that there is no haplotype overlap among the species, and that the haplotypes of same species are more closely related to each other when compared with others (Figure 5a). AMOVA analysis returned values of $\Phi_{\mathrm{ST}}=0.69829$. Regarding populational structuration inference, the analysis generated by BAPS indicated that there is no sequence overlap, thus evidencing independent groups (Figure 5b).

\section{Discussion}

Parodontids are mostly rheophilic, and therefore absent in the lower regions of the Amazon basin. However, the Apareiodon species from the upland rivers of the Amazon basin are morphologically less similar to Apareiodon sp. from the Aripuanã River than to congeners from the La Plata basin. In the body, the wide longitudinal stripe of Apareiodon sp. showed relatively similar patterns to Apareiodon species from the Paraná-Paraguai system $(A$.

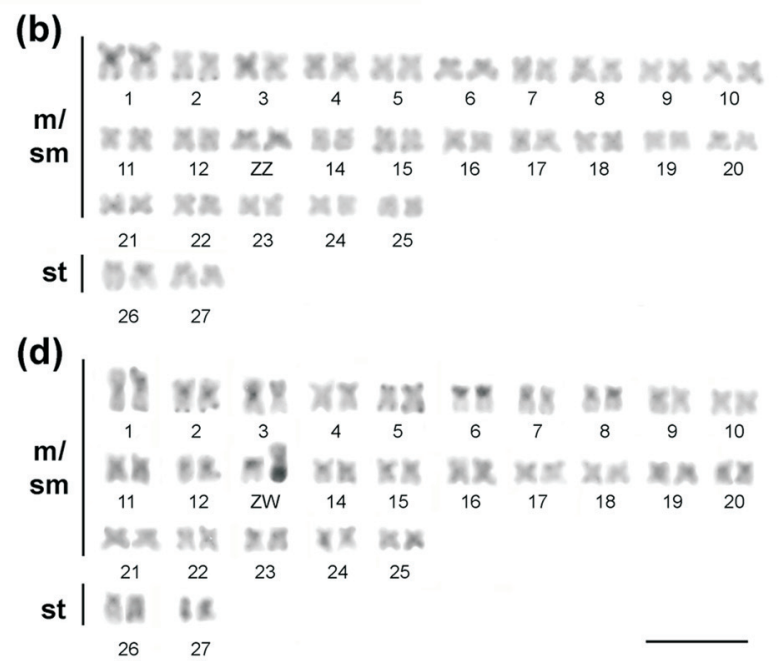

Figure 2 - Karyotypes of the males (a, b) and females (c, d) Apareiodon sp. specimens. Giemsa staining (a, c) and C-banding (b, d). Bar = $10 \mu \mathrm{m}$. 


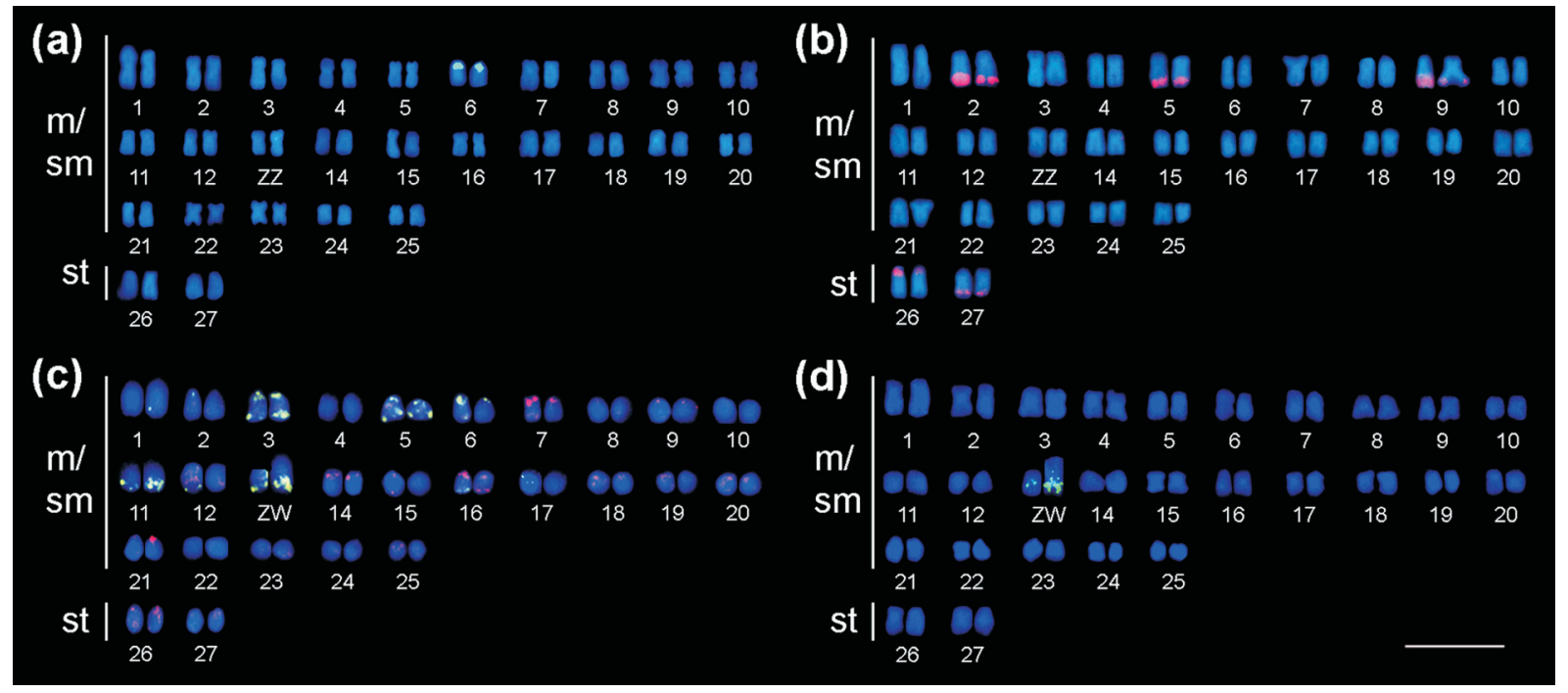

Figure 3 - Karyotypes of the Apareiodon sp. submitted to probing for in situ localization: in (a) 5S rDNA (green); (b) 18S rDNA (red); (c) pPh 2004 (green) and (GATA)n (red) and; (d) WAp probe (green). Bar $=10 \mu \mathrm{m}$.

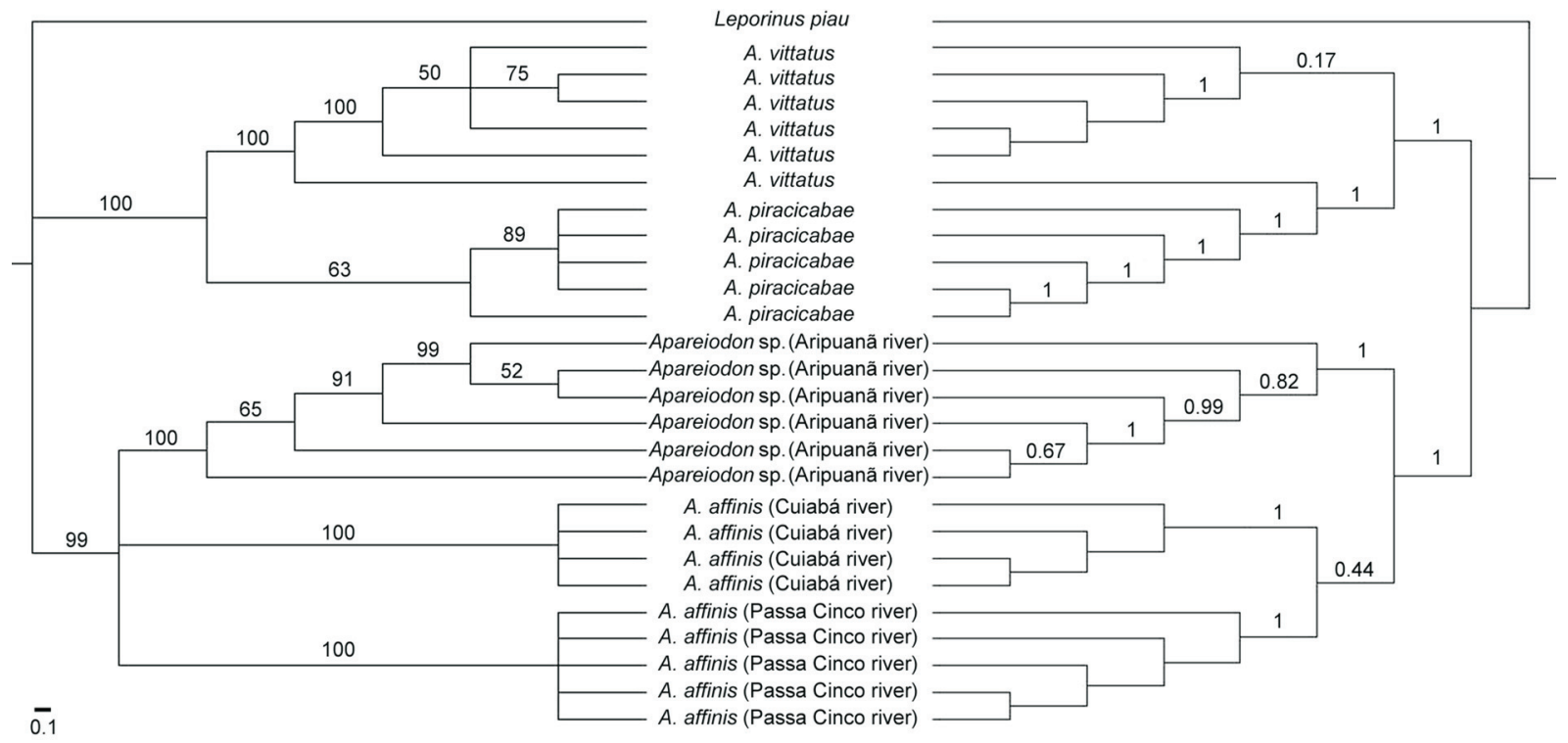

Figure 4 - Species tree showing phylogenetic relationships from the five analyzed species/populations of Parodontidae. To the left, topology for Maximum Likelihood (numbers on the branches are bootstrap values). To the right, Bayesian tree (numbers on the branches are posterior probability). The scale bar indicates nucleotide substitutions per site.

Table 1 - Estimates of evolutionary divergence over sequence pairs among groups.

\begin{tabular}{|c|c|c|c|c|c|}
\hline Species & $\begin{array}{l}\text { Apareiodon sp. } \\
\text { (Aripuanã) }\end{array}$ & A. vittatus & A. affinis (Cuiabá) & $\begin{array}{l}\text { A. affinis (Passa } \\
\text { Cinco) }\end{array}$ & A. piracicabae \\
\hline \multicolumn{6}{|l|}{ Apareiodon sp. (Aripuanã) } \\
\hline Apareiodon vittatus & $0.217( \pm 0.02)$ & & & & \\
\hline Apareiodon affinis (Cuiabá) & $0.215( \pm 0.02)$ & $0.228( \pm 0.02)$ & & & \\
\hline $\begin{array}{l}\text { Apareiodon affinis (Passa } \\
\text { Cinco) }\end{array}$ & $0.205( \pm 0.02)$ & $0.206( \pm 0.02)$ & $0.059( \pm 0.01)$ & & \\
\hline Apareiodon piracicabae & $0.233( \pm 0.02)$ & $0.151( \pm 0.01)$ & $0.098( \pm 0.01)$ & $0.077( \pm 0.01)$ & \\
\hline Intraspecific divergence & $0.042( \pm 0.01)$ & $0.033( \pm 0.00)$ & $0.00( \pm 0.00)$ & $0.000( \pm 0.00)$ & $0.000( \pm 0.00)$ \\
\hline
\end{tabular}

The number of base substitutions per site from averaging overall sequence pairs between groups are shown. Kimura-2-Parameters genetic distance mean and standard error. Analyses were conducted using the Kimura 2-parameter model. The analysis involved 26 nucleotide sequences. Codon positions included were 1st $+2 \mathrm{nd}+3 \mathrm{rd}$. All positions containing gaps and missing data were eliminated. There was a total of 441 positions in the final dataset. 
(a) ${ }_{\text {Apareiodon vittatus }}$

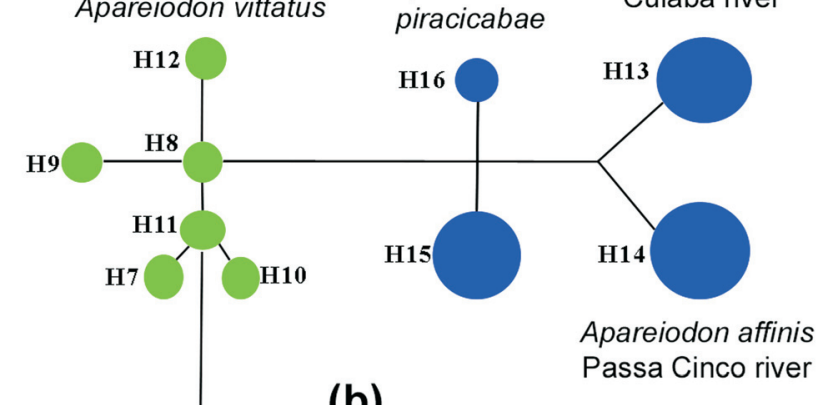

(b)

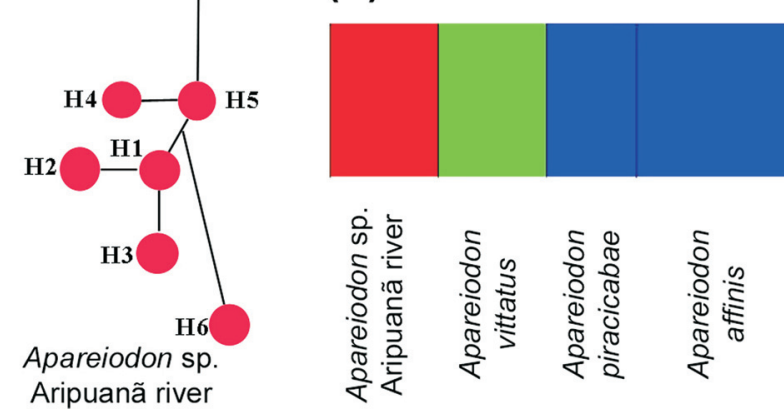

Figure 5 - Molecular data of Apareiodon sp. from the Aripuanã River. In (a), the Median Joining haplotype network of Apareiodon sp., A. vitattus, A. piracicabae, and $A$. affinis using COI gene data. The haplotypes are shown in different colors according to species or MOTU. In (b), BAPs data for the five analyzed species/populations of Parodontidae. The MOTU for Apareiodon sp. (Aripuanã River) is shown in red color.

vittatus, A. piracicabae, and A. affinis), except for the black stripe at the dorsal fin. Ingenito and Buckup (2005) inferred that these similarities in color pattern between several Parodontidae species are suggestive of close relationship, but should be evaluated in a phylogenetic context. In addition to body color, the symphysial teeth with rounded edges and 9 to 11 cusps overlap in shape and cusp numbers with those of A. piracicabae from the upper Paraná and upper São Francisco river basins (Pavanelli, 2006).

Nevertheless, cytogenetic and DNA barcode data show a clear speciation scenario. Although having a diploid number $(2 \mathrm{n}=54)$, a chromosomal formula $(50 \mathrm{~m} / \mathrm{sm}+4 \mathrm{st})$, a FN value (108), and localization of 5S rDNA sequences in a single chromosomal pair, similar to other species of the genus (Bellafronte et al., 2011; Schemberger et al., 2011; Traldi et al., 2016), a set of chromosomal markers were able to differentiate Apareiodon sp. from other congeneric species. Regarding chromosomal differences in Apareiodon sp., this species shows an exclusive number of five chromosome pairs bearing major rDNA sequences (18S rDNA probe) among the Parodontidae species; the $\mathrm{W}$ chromosome differs from the other Parodontidae with a ZZ/ZW sex chromosome system by the exclusive localization of the satellite $\mathrm{pPh} 2004$ in the $\mathrm{q}$ arm, and by having a high number of pPh2004 sites in exclusive chromosomal localization of the karyotype.
The 18S rDNA sites occupies the long arm terminal region of a single large subtelocentric chromosome pair in most species of Apareiodon (Moreira-Filho et al., 1984, 1985; Rosa et al., 2006; Vicari et al., 2006). Even though there are some few exceptions for multiple 18S rDNA sites occuring in Apareiodon (Bellafronte et al., 2009; Traldi et al., 2016), there is no case with such a high number as in Apareiodon sp., which may be related to some distinct chromosomal rearrangements, such as inversions, translocations and transposon-mediated transpositions (Symonová et al., 2013; Barbosa et al., 2017). On the other hand, the 5S rDNA localization is a conserved trait in the Parodontidae, where the chromosome pair bearing these sequences appears as homologue in most species (Bellafronte et al., 2009, 2011). Additional 5S rDNA sites are a rare occurrence, and only Parodon nasus and A. affinis showed this site at a different chromosome and position (Bellafronte et al., 2009; Traldi et al., 2016; do Nascimento et al., 2018).

It was proposed that the differentiation of the $\mathrm{ZZ/ZW}$ sex system in Parodontidae is related to a paracentric inversion, in which the terminal $\mathrm{W} A p$ repetitive sequence was transposed to the proximal region of the short arm of a metacentric pair, with subsequent amplification leading to the differentiation of the $\mathrm{W}$ chromosome (Centofante et al., 2002; Vicente et al., 2003; Schemberger et al., 2011). Apparently, only Apareiodon hasemani presents a distinct stage of heterochromatinization on the $\mathrm{p}$ arm (Bellafronte et al., 2012). In Parodon moreirai and P. hilarii, the Z chromosome presents satellite DNA at the terminal region of the $\mathrm{q}$ arm, while the $\mathrm{W}$ chromosome has $\mathrm{pPh} 2004$ in the PRA (pseudo-autosomal region located at $\mathrm{p}$ arm), and $\mathrm{W} A p$ and GATAn sequences at the WSR (W specific region located at $\mathrm{q}$ arm). The $\mathrm{W}$ chromosome of Apareiodon sp. differs by the exclusive localization of the satellite $\mathrm{p} P h 2004$ in the q arm. However, the WSR of Apareiodon sp. keeps its repetitive sequences concerning the $\mathrm{W} A p$ probe identical to other Paradontidae, with exception of the GATAn expansion, which does not show accumulation in this chromosome.

In addition to the exclusive condition of the $\mathrm{pPh} 2004$ site in the q arm in the $\mathrm{W}$ chromosome of Apareiodon sp., this species possesses a high number of pPh2004 sites (14) distributed in three autosomal and ZW chromosomes. Karyotypes presenting numerous pPh2004 sites were described for $P$. nasus, $P$. hilarii, and $A$. affinis (Centofante $e t$ al., 2002; Vicente et al., 2003; do Nascimento et al., 2018), but the chromosomal sites localization is quite divergent in relation to Apareiodon sp. (Aripuanã River). All these cytogenetic features corroborate with the barcode, haplotypic network, and BAPs data, which demonstrate differentiation and absence of gene flow between Apareiodon sp. and the other Apareiodon species with a similar body color pattern.

DNA barcode studies have been useful in demonstrating genetic divergence among Parodontidae species, such 
as $A$. affinis, A. ibitiensis, A. piracicabae, A. vitattus, $A$. vladii, Apareiodon sp. from Verde River, $P$. nasus and $P$. moreirai (Bellafronte et al., 2013), all well morphologically supported clades. The comparative population studies of $A$. affinis were equally informative, evidencing that the species from the upper Paraná differ from those of the lower Paraná River basin, and that three populations from the lower Paraná system (Uruguai, Paraguai, and Cuiabá rivers) display divergent chromosomal features, as well as low values of genetic divergence, which could indicate possible parapatric speciation processes in progress (do Nascimento et al., 2018). In our study, Apareiodon sp. represents the only Amazonian species (Madeira basin) that was compared to other Apareiodon species with a similar color pattern (A. piracicabae, A. vittatus, A. affinis), all of them from the Paraná River basin, and the results showed that Apareiodon sp. from the Aripuanã river belong to an undescribed species in the literature.

According to Lundberg (1998), the modern separation between the Paraná and Amazon systems occurred about 30 Myr ago. Since then, headwater captures among rivers from these hydrographic systems were also documented to have occurred during the last $10 \mathrm{Myr}$ (Lundberg, 1998). The results of K2P genetic divergence demonstrated that Apareiodon sp. is distant by $20-23 \%$ from other Apareiodon evaluated, these high $\mathrm{K} 2 \mathrm{P}$ values being compatible with distinct fish species (Hebert et al., 2003; Ward et al., 2005, 2009). Thus, although probable fauna interchanges occurred between the Paraná and Amazon systems, the population structure analysis, in addition to $\mathrm{K} 2 \mathrm{P}$ genetic divergence evidenced that Apareiodon sp. appears as a distinct biological entity inside Parodontidae.

The haplotype network shows no overlap between Apareiodon sp., A. vittatus, A. piracicabae, and A. affinis COI haplotypes, corroborating absence of gene flow and isolation among these species. A similar case was demonstrated for Leporinus friderici as a new MOTU in the Madeira basin, which also demonstrated gene flow isolation to other Leporinus friderici in the Amazon and Paraná basins (Silva-Santos et al., 2018). Within the Amazon basin itself, Apareiodon sp. seems to be morphologically different from congeners, and apparently it is not found outside the Madeira River basin (Pedroza et al., 2012; Fernandes et al., 2013).

Our phylogenetic analyses showed that specimens, although morphologically similar, compose particular groups in distinct branches with high support values, indicating clades that have ancient segregations. The close relationship of Apareiodon sp. and A. affinis, from the ParanáParaguai system, indicates some current or recent connections between the basins, corroborating data by Brea and Zucol (2011) and Dagosta and De Pinna (2017). In this scenario, population genetics data, in addition to particular cytogenetic characteristics, indicate that Apareiodon sp. from the Aripuanã River differentiated from morphologi- cally close congeneric species and appears as a new Molecular Operational Taxonomic Unit (MOTU) within the Parodontidae.

\section{Acknowledgments}

The authors are grateful to ICMBio (Instituto Chico Mendes de Conservação da Biodiversidade) (license number 10538-1 to collect specimens) and to Luis Henrique da Silva for technical support. This study was financially supported by Fundação Araucária (Fundação Araucária de Apoio ao Desenvolvimento Científico e Tecnológico do Estado do Paraná), FAPESP (Fundação de Amparo à Pesquisa do Estado de São Paulo), Fapemat (Fundação de Amparo à Pesquisa do Estado de Mato Grosso), Coordenação de Aperfeiçoamento de Pessoal de Nível Superior - Brasil (CAPES) - Finance Code 001, and CNPq (Conselho Nacional de Desenvolvimento Científico e Tecnológico).

\section{Conflict of interest}

The authors have no conflicts of interest to declare.

\section{Author contributions}

EOS, CSP, OMF, MRV conceived and designed the study; EAO, HPS, OMF collected the samples; HPS, CSP analyzed the morphological data; EOS, GAD, EZO, VN, MRV conducted the cytogenetic experiments; GAD, RBA, MRV analyzed the COI data; EOS, GAD, RBA, HPS were involved in the manuscript draft; VN, CSP, MMC, LACB, OMF, MRV have contributed to the planning of the study and manuscript writing; all authors read and approved the final version.

\section{References}

Barbosa P, Pucci MB, Nogaroto V, Almeida MC, Artoni RF and Vicari MR (2017) Karyotype analysis of three species of Corydoras (Siluriformes: Callichthyidae) from southern Brazil: rearranged karyotypes and cytotaxonomy. Neotrop Ichthyol 15:e160056.

Barros AV, Wolski MAV, Nogaroto V, Almeida MC, MoreiraFilho O and Vicari MR (2017) Fragile sites, dysfunctional telomere and chromosome fusions: What is $5 \mathrm{~S}$ rDNA role? Gene 608:20-27.

Bellafronte E, Vicari MR, Artoni RF, Margarido VP and Moreira-Filho O (2009) Differentiated ZZ/ZW sex chromosomes in Apareiodon ibitiensis (Teleostei, Parodontidae): cytotaxonomy and biogeography. J Fish Biol 75:2313-2325.

Bellafronte E, Schemberger MO, Moreira-Filho O, Almeida MC, Artoni RF, Margarido VP and Vicari MR (2011) Chromosomal markers in Parodontidae: An analysis of new and reviewed data with phylogenetic inferences. Rev Fish Biol Fish 21:559-570.

Bellafronte E, Schemberger MO, Artoni RF, Moreira-Filho O and Vicari MR (2012) Sex chromosome system ZZ/ZW in Apareiodon hasemani Eigenmann, 1916 (Characiformes, 
Parodontidae) and a derived chromosomal region. Genet Mol Biol 35:770-776.

Bellafronte E, Mariguela TC, Pereira LHG, Oliveira C and Moreira-Filho O (2013) DNA barcode of Parodontidae species from the La Plata River basin aplying new data to clarify taxonomic problems. Neotrop Ichthyol 11:497-506.

Bertollo LAC, Moreira-Filho O and Cioffi MB (2015) Direct chromosome preparations from freshwater teleost fishes. In: Ozouf-Costaz C, Pisano E, Foresti F and Almeida Toledo LF (eds) Fish techniques, Ray-Fin Fishes and Chondrichthyans. CRC Press, Boca Raton, pp 21-26.

Brea M and Zucol AF (2011) The Paraná-Paraguay Basin: geology and paleoenvironments. In: Albert JS and Reis RE (eds) Historical biogeography of Neotropical freshwater fishes. University of California Press, Berkeley, pp 69-87.

Carvalho DC, Oliveira DAA, Pompeu PS, Leal CG, Oliveira C and Hanner R (2011) Deep barcode divergence in Brazilian freshwater fishes: The case of the São Francisco River basin. Mitochondrial DNA 22:80-86.

Centofante L, Bertollo LAC and Moreira-Filho O (2002) ZZ/ZW sex chromosome system in new species of the genus Parodon (Pisces, Parodontidae). Caryologia 54:139-150.

Corander J and Marttinen P (2006) Bayesian identification of admixture events using multilocus molecular markers. Mol Ecol 15:2833-2843.

Corander J, Waldmann P, Marttinen P and Sillanpää MJ (2004) BAPS 2: Enhanced possibilities for the analysis of genetic population structure. Bioinformatics 20:2363-2369.

Cunha WT, Santos RC, Araripe J, Sampaio I, Schneider H and Rêgo PS (2017) Molecular analyses reveal the occurrence of three new sympatric lineages of velvet worms (Onychophora: Peripatidae) in the eastern Amazon basin. Genet Mol Biol 40:147-152.

Dagosta FCP and de Pinna M (2017) Biogeography of Amazonian fishes: Deconstructing river basins as biogeographic units. Neotrop Ichthyol 15:e170034.

do Nascimento VD, Coelho KA, Nogaroto V, Almeida RB, Ziemniczak K, Centofante L, Pavanelli CS, Torres RA, MoreiraFilho O and Vicari MR (2018) Do multiple karyomorphs and population genetics of freshwater darter characines (Apareiodon affinis) indicate chromosomal speciation? Zool Anz 272:93-103.

Eschmeyer WN and Fong JD (2017) Species by family/subfamily. In: Eschmeyer WN (ed) Catalog of fishes. California Academy of Sciences, San Francisco.

Excoffier L, Smouse PE and Quattro JM (1992) Analysis of molecular variance inferred from metric distances among DNA haplotypes: Application to human mitochondrial DNA restriction data. Genetics 131:479-491.

Excoffier L and Lischer HE (2010) Arlequin suite ver 3.5: A new series of programs to perform population genetics analyses under Linux and Windows. Mol Ecol Resour 10:564-567.

Fernandes IM, Lourenço LS, Ota RP, Moreira MM and Zawadzki $\mathrm{CH}$ (2013) Effects of local and regional factors on the fish assemblage structure in Meridional Amazonian streams. Environ Biol Fishes 96:837-848.

Floyd R, Eyualem A, Papert A and Blaxter M (2002) Molecular barcodes for soil nematode identification. Mol Ecol 11:839-850.

Gross MC, Schneider CH, Valente GT, Martins C and Feldberg E (2010) Variability of 18S rDNA locus among Symphysodon fishes: chromosomal rearrangements. J Fish Biol 76:1117-1127.

Hebert PD, Cywinska A, Ball SL and Dewaard JR (2003) Biological identifications through DNA barcodes. Proc Biol Sci 270:313-321.

Huelsenbeck JP and Ronquist F (2001) MRBAYES: Bayesian inference of phylogeny. Bioinformatics 17:754-755.

Ingenito LF and Buckup PA (2005) A new species of Parodon from the Serra da Mantiqueira, Brazil (Teleostei: Characiformes: Parodontidae). Copeia 2005:765-771.

Jesus CM and Moreira-Filho O (2000) Cytogenetic studies in some Apareiodon species (Pisces, Parodontidae). Cytologia 65:397-402.

Jorge LC and Moreira-Filho O (2000) Cytogenetic studies on Apareiodon affinis (Pisces, Characiformes) from Paraná river basin: Sex chromosomes and polymorphism. Genetica 109:267-273.

Jorge LC and Moreira-Filho O (2004) Nucleolar organizer regions as markers of chromosomal polymorphism in Apareiodon affinis (Pisces, Parodontidae). Caryologia 57:203-207.

Kearse M, Moir R, Wilson A, Stones-Havas S, Cheung M, Sturrock S, Buxton S, Cooper A, Markowitz S, Duran C et al. (2012) Geneious Basic: An integrated and extendable desktop software platform for the organization and analysis of sequence data. Bioinformatics 28:1647-1649.

Kimura M (1980) A simple method of estimating evolutionary rate of base substitutions through comparative studies of nucleotide sequences. J Mol Evol 16:111-120.

Kumar S, Glen Stecher G and Tamura K (2016) Mega7: Molecular Evolutionary Genetics Analysis Version 7.0 for bigger datasets. Mol Biol Evol 33:1870-1874.

Leigh JW and Bryant D (2015) POPART: Full-feature software for haplotype network construction. Methods Ecol Evol 6:1110-1116.

Levan A, Fredga K and Sandberg AA (1964) Nomenclature for centromeric position on chromosomes. Hereditas 52:201220 .

Librado P and Rozas J (2009) DnaSP v5: A software for comprehensive analysis of DNA polymorphism data. Bioinformatics 25:1451-1452.

Lundberg JG (1998) The temporal context for the diversification of Neotropical fishes. In: Reis RE, Vari RP, Lucena ZM and Lucena CAS (eds) Phylogeny and classification of neotropical fishes. Edipucrs, Porto Alegre, pp 13-48.

Machado CDB, Ishizuka TK, Freitas PD, de Valiati VH and Galetti PM (2016) DNA barcoding reveals taxonomic uncertainty in Salminus (Characiformes). Syst Biodivers 15:372-382.

Moreira-Filho O, Bertollo LAC and Galetti Jr PM (1980) Evidences for a multiple sex chromosome system with female heterogamety in Apareiodon affinis (Pisces, Parodontidae). Caryologia 33:83-91.

Moreira-Filho O, Bertollo LAC and Galetti Jr PM (1984) Structure and variability of nucleolar organizer regions in Parodontidae fish. J Genet Cytol 26:564-568.

Moreira-Filho O, Bertollo LAC and Galetti Jr PM (1985) Karyotypic study of some species of family Parodontidae (Pisces-Cypriniformes). Caryologia 38:47-55. 
Murray MG and Thompson WF (1980) Rapid isolation of high molecular weight plant DNA. Nucleic Acids Res 8:4321-4325.

Pavanelli CS (2006) New species of Apareiodon (Teleostei: Characiformes: Parodontidae) from the rio Piquiri, upper rio Paraná basin, Brazil. Copeia 2006:89-95.

Pavanelli CS and Britski HA (2003) Apareiodon Eigenmann, 1916 (Teleostei, Characiformes), from the Tocantins-Araguaia Basin, with description of three new species. Copeia 2:337-348.

Pedroza WS, Ribeiro FRV, Teixeira TF, Ohara WM and PyDaniel LHR (2012) Ichthyofaunal survey of stretches of the Guariba and Rooselvelt Rivers, in Guariba State Park and Guariba Extractive Reserve, Madeira River basin, Amazonas, Brazil. Check List 8:8-15.

Pereira LHG, Maia GMG, Hanner R, Foresti F and Oliveira C (2011) DNA barcodes discriminate freshwater fishes from the Paraíba do Sul River Basin, São Paulo, Brazil. Mitochondrial DNA 22:71-79.

Pereira LHG, Hanner R, Foresti F and Oliveira C (2013) Can DNA barcoding accurately discriminate megadiverse Neotropical freshwater fish fauna? BMC Genet 14:20.

Pinkel D, Straume T and Gray JW (1986) Cytogenetic analysis using quantitative, high-sensitivity, fluorescence hybridization. Proc Natl Acad Sci U S A 83:2934-2938.

Pritchard JK, Stephens M and Donnelly PJ (2000) Inference of population structure using multilocus genotype data. Genetics 155:945-959.

Posada D (2003) Using Modeltest and PAUP* to select a model of nucleotide substitution. Curr Prot Bioinformatics 6:5.

Ramirez JL and Galetti Jr PM (2015) DNA barcode and evolutionary relationship within Laemolyta Cope 1872 (Characiformes: Anostomidae) through molecular analyses. Mol Phylog Evol 93:77-82.

Ramirez JL, Birindelli JL, Carvalho DC, Affonso PRAM, Venere PC, Ortega H, Carrillo-Avila M, Rodríguez-Pulido JA and Galetti Jr. PM (2017) Revealing hidden diversity of the underestimated neotropical ichthyofauna: DNA barcoding in the recently described genus Megaleporinus (Characiformes: Anostomidae). Front Genet 8:149.

Ronquist F and Huelsenbeck JP (2003) MrBayes 3: Bayesian phylogenetic inference under mixed models. Bioinformatics 19:1572-1574.

Rosa R, Bellafronte E, Moreira-Filho O and Margarido VP (2006) Description of the ZZ/ZW sex chromosome system and localization of 5S and 18S rDNA genes in Apareiodon sp. (Pisces, Characiformes, Parodontidae). Genetica 128:159-166.

Schemberger MO, Bellafronte E, Nogaroto V, Almeida MC, Schühli GS, Artoni RF, Moreira-Filho O and Vicari MR (2011) Differentiation of repetitive DNA sites and sex chromosome systems reveal closely related group in Parodontidae (Actinopterygii: Characiformes). Genetica 139:14991508 .

Schemberger MO, Oliveira JIN, Nogaroto V, Almeida MC, Artoni RF, Cestari MM, Moreira-Filho $\mathrm{O}$ and Vicari MR (2014) Construction and characterization of a repetitive DNA library in Parodontidae (Actinopterygii: Characifor- mes): A genomic and evolutionary approach to the degeneration of the W sex chromosome. Zebrafish 11:518-527.

Schemberger MO, Nogaroto V, Almeida MC, Artoni RF, Valente GT, Martins C and Vicari MR (2016) Sequence analyses and chromosomal distribution of the Tc1/Mariner element in Parodontidae fish (Teleostei: Characiformes). Gene 593:308-314.

Silva-Santos R, Ramirez JL, Galetti Jr PM and Freitas PD (2018) Molecular evidences of a hidden complex scenario in Leporinus cf. friderici. Front Genet 9:47.

Sumner AT (1972) A simple technique for demonstrating centromeric heterocromatin. Exp Cell Res 75:304-306.

Symonová R, Majtánová Z, Sember A, Staaks GBO, Bohlen J, Freyhof J, Rábová M and Ráb P (2013) Genome differentiation in a species pair of coregonine fishes: An extremely rapid speciation driven by stress-activated retrotransposons mediating extensive ribosomal DNA multiplications. BMC Evol Biol 13:42.

Traldi JB, Blanco DR, Vicari MR, Martinez JDEF, Lui RL, Artoni RF and Moreira-Filho O (2013) Physical mapping of (GATA) $n$ and (TTAGGG) $n$ sequences in species of Hypostomus (Siluriformes, Loricariidae). J Genet 92:127-130.

Traldi JB, Vicari MR, Martinez JDF, Blanco DR, Lui RL and Moreira-Filho O (2016) Chromosome analyses of Apareiodon argenteus and Apareiodon davisi (Characiformes, Parodontidae): An extensive chromosomal polymorphism of 45S and 5S ribosomal DNAs. Zebrafish 13:19-25.

Vicari MR, Moreira-Filho O, Artoni RF and Bertollo LAC (2006) $\mathrm{ZZ/ZW}$ sex chromosome system in an undescribed species of the genus Apareiodon (Characiformes, Parodontidae). Cytogenet Genome Res 114:163-168.

Vicari MR, Nogaroto V, Noleto RB, Cestari MM, Cioffi MB, Almeida MC, Moreira-Filho O, Bertollo LAC and Artoni RF (2010) Satellite DNA and chromosomes in neotropical fishes: Methods, applications and perspectives. J Fish Biol 76:1094-1116.

Vicente VE, Bertollo LAC, Valentini SR and Moreira-Filho O (2003) Origin and differentiation of sex chromosome system in Parodon hilarii (Pisces, Parodontidae). Satellite DNA, G and C-banding. Genetica 119:115-120.

Ward RD, Zemlak TS, Innes BH, Last PR and Hebert PDN (2005) DNA barcoding Australia's fish species. Philos Trans R Soc Lond B Biol Sci 360:1847-1857.

Ward RD, Hanner R and Hebert PDN (2009) The campaign to DNA barcode all fishes, FISH-BOL. J Fish Biol 74:329-356.

Ziemniczak K, Traldi JB, Nogaroto V, Almeida MC, Artoni RF, Moreira-Filho O and Vicari MR (2014) In situ localization of (GATA)n and (TTAGGG)n repeat DNAs and W sex chromosome differentiation in Parodontidae (Actinopterygii: Characiformes). Cytogenet Genome Res 144:325-332.

Associate Editor: Yatiyo Yonenaga-Yassuda

License information: This is an open-access article distributed under the terms of the Creative Commons Attribution License (type CC-BY), which permits unrestricted use, distribution and reproduction in any medium, provided the original article is properly cited. 